\title{
Estimation of Nitrate Contamination of an Agro-Ecosystem Outwash Aquifer Using a Nitrogen Mass-Balance Budget
}

\author{
Larry J. Puckett,* Timothy K. Cowdery, David L. Lorenz, and Jeffrey D. Stoner \\ L.J. Puckett, U.S. Geological Survey, 413 National Center, Reston, VA 20192; T.K. Cowdery and D.L. Lorenz, U.S. \\ Geological Survey, 2280 Woodale Road, Mounds View, MN 55112; and J.D. Stoner, U.S. Geological Survey, \\ Denver Federal Center, MS 415, Lakewood, CO 80225. Received 1 Feb. 1999. *Corresponding author \\ (lpuckett@usgs.gov). \\ Journal of Environmental Quality, 28:2015-2025 (1999).
}

Abbreviations: BP, before present; PVC, polyvinyl chloride; GIS, geographic information system; DOC, dissolved organic carbon; DO, dissolved oxygen.

\begin{abstract}
A mass-balance budget of $\mathrm{N}$ cycling was developed for an intensive agricultural area in west-central Minnesota to better understand $\mathrm{NO}_{3}{ }^{-}$contamination of ground water in the Otter Tail outwash aquifer. Fertilizer, biological fixation, atmospheric deposition, and animal feed were the $\mathrm{N}$ sources, and crop harvests, animal product exports, volatilization from fertilizer and manure, and denitrification were the $\mathrm{N}$ sinks in the model. Excess $\mathrm{N}$, calculated as the difference between the sources and sinks, was assumed to leach to ground water as $\mathrm{NO}_{3}{ }^{-}$. The budget was developed using ground water data collected throughout the $212-\mathrm{km}^{2}$ study area. Denitrification was estimated by adjusting its value so the predicted and measured concentrations of $\mathrm{NO}_{3}{ }^{-}$in ground water agreed. Although biological fixation was the largest single $\mathrm{N}$ source, most was removed when crops were harvested, indicating that inorganic fertilizer was the primary source of $\mathrm{N}$ reaching the water table. It was estimated that denitrification removed almost half of the excess $\mathrm{NO}_{3}{ }^{-}$that leached below the root zone. Even after accounting for denitrification losses, however, it was concluded that the ground water system was receiving approximately three times as much $\mathrm{N}$ as would be expected under background conditions.
\end{abstract}

The $\mathrm{N}$ cycle of agro-ecosystems is by definition dominated by agricultural sources and sinks, the magnitude of which greatly exceeds natural cycles that evolved over many millennia. Agricultural inputs of $\mathrm{N}$ in the USA have increased 20-fold in the past $50 \mathrm{yr}$, and the most dramatic increases have taken place in the past $30 \mathrm{yr}$ (Puckett, 1995). Vitousek (1994) has estimated that of the total $\mathrm{N}$ used by humans throughout history up to 1992, approximately half was applied from 1982 to 1992. Consequently, many agro-ecosystems and their associated ground water and surface water systems may still be receiving increasing $\mathrm{N}$ amounts.

One of the least appreciated components of the alteration of the natural cycle is the dramatic increase in $\mathrm{N}$ inputs caused by increased cultivation of $\mathrm{N}$ fixing crops such as alfalfa (Medicago sativa L.), soybean [Glycine $\max$ (L.) Merr.], and other legumes. These crops have a much greater capacity to fix atmospheric $\mathrm{N}$ than natural vegetation. For example, alfalfa can fix approximately $218 \mathrm{~kg} \mathrm{~N} \mathrm{ha}^{-1} \mathrm{yr}^{-1}$, whereas deciduous forests can fix only about $12 \mathrm{~kg} \mathrm{~N} \mathrm{ha}^{-1} \mathrm{yr}^{-1}$ (Keeney, 1979; Jordan and Weller, 1996). In some agro-ecosystems, legume fixation may even be the largest source of N. For example, Keeney (1979) estimated that for the state of Wisconsin, 
$\mathrm{N}$ fixation by legumes exceeded inputs from commercial fertilizer by 2.5 times. Peterson and Russelle (1991) estimated that for the eight states of the U.S. Corn Belt, alfalfa alone contributed $1 \times 10^{9} \mathrm{~kg}$ of $\mathrm{N}$ compared with $4 \times 10^{9} \mathrm{~kg}$ from commercial fertilizer. It is important to consider this $\mathrm{N}$ source because it may contribute $\mathrm{NO}_{3}{ }^{-}$to ground water and surface waters either directly through $\mathrm{N}$ added to the soil or indirectly as the result of mineralization of plant residues or animal manure.

Nitrate contamination is important both from a human health and an ecosystem perspective. The USEPA has set a maximum contaminant level of $10 \mathrm{mg} \mathrm{L}^{-1} \mathrm{NO}_{3}-\mathrm{N}$ for drinking water (USEPA, 1996), whereas $\mathrm{NO}_{3}{ }^{-}$in ground water discharging to surface waters can support eutrophication, degrading aquatic ecosystems. Furthermore, recent studies have shown that ground water residence times of $50 \mathrm{yr}$ or more are common (Bohlke and Denver, 1995; Modica et al., 1998). In areas where ground water $\mathrm{NO}_{3}{ }^{-}$concentrations are at historically high levels, we may expect $\mathrm{NO}_{3}{ }^{-}$discharges to surface water to continue for many years unless there are mitigating biogeochemical processes along ground water flow paths. Consequently, it is important to understand the biogeochemical processes, such as denitrification, that may alter $\mathrm{N}$ concentrations in ground water systems.

A number of recent studies have identified $\mathrm{N}$ sources and have presented mass-balance budgets at various scales (Correll et al., 1992; Jaworski et al., 1992; Barry et al., 1993; Puckett, 1995; Jordan and Weller, 1996; McMahon and Woodside, 1997). However, only one study (Hall and Risser, 1993) has shown a direct link to ground water $\mathrm{NO}_{3}{ }^{-}$concentrations. Because of a general lack of reliable ground water quality data, most studies of this kind have either ignored it altogether or incorporated it as part of storage within the system. Furthermore, because of the lack of a complete system analysis, previous studies have only been able to speculate on the magnitude of denitrification.

There is a great need for mass-balance studies of agro-ecosystems at various scales to better understand the role of ground water as a reservoir and/or sink for $\mathrm{N}$ in the environment and to improve $\mathrm{N}$ management strategies for water quality purposes. Furthermore, glacial outwash covers large areas of previously glaciated portions of North America now under intensive cultivation. Because these outwash materials are well drained, and in many areas are under intensive agricultural cultivation, they are potentially vulnerable to ground water contamination. In this article, we present a $\mathrm{N}$ mass-balance budget of an agro-ecosystem located on an outwash aquifer in west-central Minnesota, based on systematically collected ground water quality data. Our objective is to demonstrate that excess $\mathrm{N}$ can be used to estimate ground water $\mathrm{NO}_{3}{ }^{-}$ concentrations in well-drained outwash settings and that denitrification can be a significant $\mathrm{N}$ sink.

\section{STUDY AREA}

This study was conducted in Otter Tail County in west-central Minnesota, USA (Fig. 1). Three study areas are discussed in this report. The primary study area is limited to the Otter Tail outwash aquifer section north of Rush Lake (Fig. 1) and covers $212 \mathrm{~km}^{2}$ in east-central Otter Tail 
County. A smaller, 36- $\mathrm{km}^{2}$ subunit in the aquifer area north of the Otter Tail River near Perham, referred to as the Perham study area, was selected for more intensive study (Fig. 1). A third study area comprised the collective recharge areas of the wells sampled, and represented $0.7 \mathrm{~km}^{2}$.

The Otter Tail outwash aquifer consists mostly of fine to coarse, fairly well sorted sand, but also contains some gravel and clay lenses. Aquifer thickness is generally about $18 \mathrm{~m}$ but may be more than $30 \mathrm{~m}$ in places (Reeder, 1972). Sediments comprising the aquifer were deposited by meandering, debris-laden streams flowing from the disintegrating margin of the Des Moines glacial lobe sometime between 14000 and $12000 \mathrm{yr}$ BP (before present) (Wright, 1972). After the outwash sands were deposited, stagnant ice blocks within the aquifer melted, forming the abundant lakes and wetland depressions common throughout the area (Goldstein, 1985).

Recharge to the aquifer occurs over much of its area from snowmelt and direct precipitation. Because of the coarse aquifer materials, recharge is rapid, taking only about 0.5 to $1 \mathrm{yr}$ for infiltrating water to reach the water table (Cowdery, 1997). Ground water flow is generally from higher elevations of the moraines on the west, north, and east sides of the aquifer toward the Otter Tail River chain of lakes in the center of the aquifer. Wetlands, lakes, and streams are in hydraulic connection with the ground water. Water loss from the aquifer is through discharge to the Otter Tail River, lakes, wetlands, wells, and through evapotranspiration.

Stoner et al. (1993) reported the climate as subhumid continental, and Winter and Woo (1990) placed the study area in the zone where open water evaporation exceeds precipitation by approximately $10 \mathrm{~cm} \mathrm{yr}^{-1}$. Annual average temperature and precipitation (including all forms) in the area during the $30-\mathrm{yr}$ period from 1966 to 1995 was $5.4^{\circ} \mathrm{C}$ and $68 \mathrm{~cm}$, respectively. From 1991 to 1995 , which includes the time period for this study, precipitation averaged $68.9 \mathrm{~cm} \mathrm{yr}^{-1}$. Historically, the study area was prairie, surrounded by hardwood and conifer forests on the morainal uplands; at the time of the study, however, approximately $73 \%$ of land was cropland.

\section{METHODS}

\section{Study Design}

Within the $212 \mathrm{~km}^{2}$ Otter Tail outwash aquifer study area, 29 well sites were chosen at random for the water quality sampling network. Wells were constructed at 22 of the sites with screens positioned to intersect the water table, whereas seven existing wells were selected for sampling. Existing wells had short screens that were close to the water table, had no confining beds separating the screen from the land surface, and were located as near as possible to the preselected randomly located sampling site. All installed wells were made of 5-cm inside diameter polyvinyl chloride (PVC) pipe with slotted $1.3 \mathrm{~m}$ long PVC screens. No foreign water was introduced into the well except deionized water where necessary for development. Depth to water ranged from 0.7 to $10.1 \mathrm{~m}$ with a median of $4.6 \mathrm{~m}$, and depth to the sampling point ranged from 1.9 to $22.3 \mathrm{~m}$ with a median of $6.7 \mathrm{~m}$. 


\section{Land Use Data}

For the study area as a whole, land use was characterized using a geographic information system (GIS) and Anderson Level II land use, land cover data compiled from aerial photography (Anderson et al., 1976). In addition, to provide information on specific crops grown in the area, inventories were made from 1993 to 1994. Land use at a well was estimated from aerial photographs after the land area contributing water to the sampled well was determined. Finally, field notes were kept of land use within the contributing areas of individual wells.

The ground water flow models MODFLOW (McDonald and Harbaugh, 1988) and MODPATH (Pollock, 1989) were used to estimate the up-gradient area most likely to contribute recharge to each sampling network well (Cowdery, 1997). A 5-layer model was constructed for a hypothetical 300 by $1500 \mathrm{~m}$ rectangular portion of the aquifer using 30 by $30 \mathrm{~m}$ cell dimensions and a representative range of average horizontal hydraulic gradients. Gradients ranged from 0.00019 beneath flat lying areas to 0.0017 beneath sloping terrain adjacent to stream valleys. Layer 1 simulated unconfined conditions and allowed inputs of the average effective recharge rate (total precipitation minus losses from runoff and evapotranspiration). By specifying constant head cells, one edge of Layer 1 represented a ground water discharge area, such as a lake or stream. The other three edges of Layer 1 and all underlying layers edges were no-flow boundaries. The bottom of Layer 5 also was a no-flow boundary to represent a confining unit below the surficial aquifer. Layers 2 to 5 had equal thickness of $3.0 \mathrm{~m}$ and combined with Layer 1 to represent a typical thickness for the aquifer ranging from 13.4 to $14.9 \mathrm{~m}$. Isotropic conditions of horizontal hydraulic conductivity and a ratio of horizontal to vertical hydraulic conductivity of 5 were assumed.

The ground water model was developed by adjusting the hydraulic conductivity (31-73 m $\left.\mathrm{d}^{-1}\right)$ and effective recharge rate $\left(17.7 \mathrm{~cm} \mathrm{yr}^{-1}\right)$ until horizontal hydraulic gradients reasonably matched those used in previous investigations and determined by water level measurements in this study. The model applied hydraulic conductivity was within the reported range of 27 to 183 $\mathrm{m} \mathrm{d}^{-1}$ (Reeder, 1972). Effective recharge compared favorably with annual average recharge rate estimated from water-level hydrograph analysis, assuming a porosity of 0.25 and a water balance based on 1994 discharge of the Otter Tail River and precipitation inputs. Surface water yield at the gauge near Perham, MN, was $1.8 \times 10^{6} \mathrm{~L} \mathrm{ha}^{-1}$ in 1994 and precipitation was $7.14 \times 10^{6} \mathrm{~L} \mathrm{ha}^{-1}$. Assuming that all ground water recharge eventually discharges to and leaves the basin in the river, the ratio of water yield to precipitation inputs $(0.252)$ represents recharge. Using this method, recharge was therefore estimated as $18.1 \mathrm{~cm}$ compared with the value of $17.7 \mathrm{~cm}$ obtained in the model.

The backward path line tracking option of MODPATH was used to compute ground water travel times and distances. All factors used in the simulations were within reasonable limits of measured or reported values (Reeder, 1972; Fetter, 1994). The model was used to estimate the radius of up-gradient areas of recharge contribution for low and high gradient conditions for the 
study area. Ground water flow lines were tracked between a 1.5-m depth below the water table (representing the sampling depth of most wells used in the study) and the up-gradient water table. Simulations also were made for a 3-m depth below the water table for low-gradient conditions. The computed time of travel ranged from $2.5 \mathrm{yr}$ for the $1.5-\mathrm{m}$ depth of either gradient condition to $4.8 \mathrm{yr}$ for the 3 -m depth of the low-gradient condition.

These model computed travel times do not account for time required for water to travel from soil surface to the water table. A review of precipitation records and ground water hydrographs suggests that a reasonable estimate of percolation time to be from 0.5 to $1 \mathrm{yr}$. Added to the model estimates, total travel times from land surface to ground water sampling depth are estimated to range from 3.0 to $5.8 \mathrm{yr}$. This range corresponds to contributing area radii of 150 to $200 \mathrm{~m}$ depending on gradient and sampling depth of each well. Land use was characterized for a $90^{\circ}$ sector within the 150 - to 200 -m radius up-gradient of a well, with the exception of two wells where a $360^{\circ}$ contributing area was used because of uncertainty about ground water flow directions. It was believed that a $90^{\circ}$ sector would be adequate to incorporate true ground water flow direction given seasonal variability and direction uncertainty.

\section{Sample Collection and Analysis}

One sample was collected from each of the 29 wells from 2 June to 26 July 1994. Major inorganic ion, nutrient, and dissolved organic carbon (DOC) concentrations were measured in all samples. Well sampling procedures are detailed in protocols by Koterba et al. (1995); Menheer and Brigham (1997) report the specific application of these protocols to this study. Water temperature, specific conductance, and dissolved oxygen (DO) concentration were continuously monitored before sample collection. When these measures stabilized, and at least three casing volumes of water had been extracted from the well, sample collection began.

Samples were filtered through a $0.45-\mu \mathrm{m}$ nitrocellulose filter (a $0.7-\mu \mathrm{m}$ silver filter was used for DOC samples). Mercuric chloride preservative was added to nutrient samples; cation samples were preserved with nitric acid. Alkalinity was determined in the field by incremental titration. Nutrient and DOC samples were shipped on ice the day of collection to the U.S. Geological Survey National Water Quality Laboratory where they were analyzed using standard methods (Fishman and Friedman, 1989; Fishman, 1993; Wershaw et al., 1987). Equipment blank samples, field blank samples, replicate samples, and spiked samples (Koterba et al., 1995; Menheer and Brigham, 1997) showed a general lack of sampling contamination.

\section{Mass-Balance Budget}

The $\mathrm{N}$ cycle in agro-ecosystems is comprised of numerous processes; however, it can be simplified as: (i) assimilation of $\mathrm{NH}_{4}{ }^{+}$and $\mathrm{NO}_{3}{ }^{-}$from fertilizer, manure, and atmospheric deposition into biomass; (ii) decomposition or mineralization of biomass to $\mathrm{NH}_{4}{ }^{+}$through ammonification; (iii) oxidation of $\mathrm{NH}_{4}{ }^{+}$to $\mathrm{NO}, \mathrm{N}_{2} \mathrm{O}, \mathrm{NO}_{2}^{-}$, and $\mathrm{NO}_{3}{ }^{-}$through nitrification; (iv) reduction of $\mathrm{NO}_{3}{ }^{-}$to $\mathrm{N}_{2} \mathrm{O}, \mathrm{NO}$, and $\mathrm{N}$ gas $\left(\mathrm{N}_{2}\right)$ through denitrification; (v) conversion of $\mathrm{N}_{2}$ to $\mathrm{NH}_{4}{ }^{+}$by $\mathrm{N}$ fixing organisms through $\mathrm{N}$ fixation; (vi) loss of $\mathrm{NH}_{3}$ either to the atmosphere by 
volatilization or retention on soil particles by sorption; (vii) retention of $\mathrm{NH}_{4}{ }^{+}$on cation exchange sites or in clay interlayers; (viii) removal of $\mathrm{N}$ in harvested crops and animals; and (ix) loss of $\mathrm{NO}_{3}{ }^{-}$to ground water by leaching (Stevenson, 1982; Anderson et al., 1989). The conceptual model for the Otter Tail outwash aquifer study area shown in Fig. 2 incorporates most components of the $\mathrm{N}$ cycle, either directly or indirectly through other processes or assumptions.

Because of coarse sandy soils, we assumed sorption and cation exchange to be minimal and contributions from mineralization of soil organic matter (other than crop residues) was negligible. If $\mathrm{N}$ in soil organic matter is accumulating or being mineralized in the system, then excess $\mathrm{N}$ would be over estimated and under estimated accordingly. Although soil organic matter content for the area is not well documented, the few values available indicate it is $<0.1 \%$ (L.J. Puckett, 1995, unpublished data). Furthermore, scientists at the University of Minnesota Agriculture Extension Service make no recommendations for $\mathrm{N}$ mineralized from soil organic matter in estimating fertilizer application rates in the study area (George Rehm, 1999, Univ. of Minnesota Extension Service, oral communication), therefore we feel justified in this assumption. Finally, it was inherent in the assumption that $\mathrm{N}$ leached to ground water as $\mathrm{NO}_{3}{ }^{-}$, and excess $\mathrm{N}$ in other forms was mineralized and/or nitrified.

The mass-balance budget of $\mathrm{N}$ sources and sinks was developed within a Lotus 123 spreadsheet ${ }^{1}$ as a series of equations that incorporates various sources and sinks within the conceptual framework shown in Fig. 2. Equations in the spreadsheet are fairly simple accounting representations of the sources and sinks. Although some components of the mass balance are static values (e.g., the total fertilizer input) the more dynamic aspects are represented by interaction terms (e.g., a rate coefficient for fertilizer volatilization). In this budget, $\mathrm{N}$ sources were assumed to be commercial fertilizer, commercial animal feed, atmospheric deposition, and $\mathrm{N}$ fixation by both natural vegetation and crops. Sinks or losses of $\mathrm{N}$ were assumed to be animal products; crop uptake and harvesting; denitrification and nitrification losses of $\mathrm{NO}, \mathrm{N}_{2} \mathrm{O}$, and $\mathrm{N}_{2}$; and volatilization from fertilizer and animal manure. Animal manure was not accounted for as a direct source because its $\mathrm{N}$ content would have originated in the various sources listed above, the exception being to account for $\mathrm{N}$ transfer in animal manure between cropland and pasturegrassland and volatilization losses.

${ }^{1}$ Commercial names are provided for purposes of identification only and should note be interpreted as an endorsement by the U.S. Geological Survey.

Atmospheric inputs were based on the average of deposition data from two nearby National Atmospheric Deposition Program-National Trends Network sites for the years 1992 to 1993 (the $2 \mathrm{yr}$ before sample collection) adjusted for dry deposition (gases, particles, aerosols) based on data from Sisterson (1990); dry deposition in North Dakota was estimated as $45 \%$ of wet and in Minnesota as $79 \%$ of wet. Typically only $\mathrm{NO}_{3}-\mathrm{N}$ is accounted for in atmospheric deposition, and $\mathrm{NH}_{4}-\mathrm{N}$ is assumed to have originated locally either from fertilizer or manure volatilization; this is done to avoid double accounting when volatilization is not estimated. However, because we estimated volatilization losses, we also included atmospheric deposition of 
$\mathrm{NH}_{4}-\mathrm{N}$ as a source.

Fertilizer N estimates were based on reported county sales in 1992, which were then reapportioned to cropland on a per-hectare basis. Most of the fertilizer used in the study area was applied as anhydrous ammonia in the spring, followed with lesser amounts of urea applied as a sidedressing. Volatilization losses of $\mathrm{NH}_{3}-\mathrm{N}$ from fertilizer were assumed to be $10 \%$ (Schlesinger and Hartley, 1992; Jordan and Weller, 1996); however, because of uncertainty associated with these rate estimates, we also estimated excess $\mathrm{N}$ at 5 and $15 \%$ volatilization rates. Removal in harvested crops was estimated based on reported crop yields (Minnesota Agric. Statistics Service, 1993), N content of those crops (The Fertilizer Inst., 1982), and inventories of crops being grown in the intensive study area near Perham. When transferring the crop harvest information from the Perham site to the Otter Tail outwash aquifer study area and the well contributing areas, it was assumed the same crops were grown in the same proportions on those areas.

Nitrogen fixation was estimated as $78 \mathrm{~kg} \mathrm{ha}^{-1} \mathrm{yr}^{-1}$ for soybean, $5 \mathrm{~kg} \mathrm{ha}^{-1} \mathrm{yr}^{-1}$ for nonlegume cropland (Messer and Brezonik, 1983; Barry et al., 1993; Jordan and Weller, 1996); $40 \mathrm{~kg} \mathrm{ha}^{-1} \mathrm{yr}^{-1}$ for edible bean (Jordan and Weller, 1996); $218 \mathrm{~kg} \mathrm{ha}^{-1} \mathrm{yr}^{-1}$ for alfalfa, $116 \mathrm{~kg} \mathrm{ha}^{-1}$ $\mathrm{yr}^{-1}$ for nonalfalfa hay (Keeney, 1979; Jordan and Weller, 1996); $20 \mathrm{~kg} \mathrm{ha}^{-1} \mathrm{yr}^{-1}$ for wetlands, water, and sediments (MacGregor and Keeney, 1975; Jordan and Weller, 1996); $15 \mathrm{~kg} \mathrm{ha}^{-1} \mathrm{yr}^{-1}$ for pastures; and $10 \mathrm{~kg} \mathrm{ha}^{-1} \mathrm{yr}^{-1}$ for forests (Burns and Hardy, 1975; Jordan and Weller, 1996).

Cattle were the only significant animal populations in the study area, and those were reapportioned from the 1992 Census of Agriculture county animal population data to the study area based on pasture area. Inputs in commercial animal feed were estimated based on animal $\mathrm{N}$ consumption rates (Thomas and Gilliam, 1977; Jordan and Weller, 1996). It was assumed that all animal feed other than hay and grass was imported from outside the area. Sinks resulting from animal product sales for human consumption were estimated as a percentage of animal consumption (Thomas and Gilliam, 1977; Jordan and Weller, 1996). Nitrogen in animal manure was estimated based on animal populations, animal manure production rates, and $\mathrm{N}$ content (Puckett, 1995). Volatilization losses of $\mathrm{NH}_{3}-\mathrm{N}$ from animal manure were assumed to be $35 \%$ of the total $\mathrm{N}$ content. This value represents a compromise between the $50 \%$ value used for Wisconsin by Keeney (1979) and the 10 to 40\% values reported by Apsimon et al. (1987) and Schlesinger and Hartley (1992). The University of Minnesota extension service reports similar values depending on application methods (Michael Schmitt, Univ. of Minnesota Extension Serv., 1999 written communication). Again, because of uncertainty of estimates, we repeated our calculations at 25 and $50 \%$ volatilization rates.

Denitrification reduces $\mathrm{NO}_{3}{ }^{-}$to $\mathrm{N}_{2}$ and nitrification oxidizes $\mathrm{NH}_{4}{ }^{+}$to $\mathrm{NO}_{3}{ }^{-}$, with production of $\mathrm{NO}$ and $\mathrm{N}_{2} \mathrm{O}$ as intermediates in both processes (Eichner, 1990; Davidson and Kingerlee, 1997; Delmas et al., 1997; Hutchinson et al., 1997; Skiba et al., 1997). Nitric oxide emission rates were estimated as $3.6 \mathrm{~kg} \mathrm{~N} \mathrm{ha}^{-1} \mathrm{yr}^{-1}$ for cropland, $0.1 \mathrm{~kg} \mathrm{~N} \mathrm{ha}^{-1} \mathrm{yr}^{-1}$ for forests, 1.2 $\mathrm{kg} \mathrm{N} \mathrm{ha}^{-1} \mathrm{yr}^{-1}$ for pasture/grass, and $0.04 \mathrm{~kg} \mathrm{~N} \mathrm{ha}^{-1} \mathrm{yr}^{-1}$ for wetlands (Davidson and Kingerlee, 1997). Nitrous oxide emission rates were only available for agricultural lands and were $2 \mathrm{~kg} \mathrm{~N}$ 
$\mathrm{ha}^{-1} \mathrm{yr}^{-1}$ for legumes and $0.014 \mathrm{~kg} \mathrm{~N}$ per kg fertilizer $\mathrm{N}$ applied to cropland or about $0.8 \mathrm{~kg} \mathrm{~N} \mathrm{ha}^{-1}$ $\mathrm{yr}^{-1}$ (Eichner, 1990). Estimates of $\mathrm{N}_{2}$ emission rates were not available and therefore are accounted for as part of the overall denitrification estimate calculated in the mass- balance.

Agricultural scientists at the University of Minnesota (Anderson et al., 1989) have classified soils in the study area as having very high probabilities of substantial $\mathrm{N}$ leaching if $\mathrm{N}$ is applied in the fall, high probabilities $(>60 \%)$ if applied in the spring before planting, and moderate (40-60\%) if applied as a postplanting side dressing. Consequently, it seemed reasonable to assume most of the excess $\mathrm{N}$ would leach rather rapidly to ground water. The difference between the sources and sinks of $\mathrm{N}$ was assumed to represent a net excess available for leaching to ground water as $\mathrm{NO}_{3}-\mathrm{N}$.

Based on the steady-state ground water model developed for the aquifer, average effective recharge to the water table was estimated at $17.7 \mathrm{~cm}\left(177 \times 10^{6} \mathrm{~L} \mathrm{~km}^{-2}\right) \mathrm{yr}^{-1}$ and it typically takes water about 4 yr to reach the 2.0-m median sampling depth (Cowdery, 1997). Predicted concentration of $\mathrm{NO}_{3}-\mathrm{N}$ in shallow ground water was calculated by dividing the amount of excess $\mathrm{N}$ by total water volume that reached the water table on an annual basis and is therefore a spatially weighted average estimate. Furthermore, the mass-balance budget assumes steady-state conditions with respect to variations in cropping patterns, climate, crop yields, $\mathrm{N}$ inputs, and changes in the soil organic matter $\mathrm{N}$ pool. The budget was calibrated using ground water quality data, and a series of calculations were run to test the implications and uncertainties of our assumptions about $\mathrm{N}$ fixation, volatilization, fertilizer application rates, and changes in precipitation and management practices.

\section{RESULTS AND DISCUSSION}

\section{Ground Water Chemistry}

Concentrations of $\mathrm{NO}_{3}-\mathrm{N}$ (Table 1) ranged from $<0.05$ to $46 \mathrm{mg} \mathrm{L}^{-1}$ with a median of 6.1 $\mathrm{mg} \mathrm{L}^{-1}$ and $43 \%$ of the 28 samples (one nutrient sample was lost at the laboratory) exceeded the USEPA maximum contaminant level of $10 \mathrm{mg} \mathrm{L}^{-1}$ (USEPA, 1996). Other forms of $\mathrm{N}$ and $\mathrm{P}$ were negligible. Median DOC concentrations of $2.1 \mathrm{mg} \mathrm{L}^{-1}$ were moderate for ground water but ranged as high as $11 \mathrm{mg} \mathrm{L}^{-1}$. Although DO concentrations were up to $10.1 \mathrm{mg} \mathrm{L}^{-1}$, the median of $3.6 \mathrm{mg}$ $\mathrm{L}^{-1}$ is well below the equilibrium value $\left(10.7 \mathrm{mg} \mathrm{L}^{-1}\right.$ at $\left.10^{\circ} \mathrm{C}\right)$ and suggests that $\mathrm{O}_{2}$ is being consumed within the system, probably to oxidize organic $\mathrm{C}$ in the outwash sediments.

In areas where virtually all the available DO is consumed, denitrification becomes the terminal electron accepting process, which leads to lower $\mathrm{NO}_{3}-\mathrm{N}$ concentrations. Once most available $\mathrm{NO}_{3}-\mathrm{N}$ is consumed, bacteria utilize $\mathrm{Mn}$ oxides and then Fe oxides as terminal electron acceptors. Under very strong reducing conditions, bacteria will turn to sulfate reduction and methanogenesis. The net result of this evolution of water chemistry is a predictable sequence where DO and then $\mathrm{NO}_{3}-\mathrm{N}$ are consumed, $\mathrm{Mn}$ and $\mathrm{Fe}$ come into solution, $\mathrm{SO}_{4}{ }^{2-}$ is consumed and $\mathrm{S}^{2-}$ may come into solution, and finally $\mathrm{CH}_{4}$ may appear in solution (Chapelle et al., 1995). 
Gillham and Cherry (1978), working in outwash deposits in southern Ontario, reported a $2 \mathrm{mg} \mathrm{L}^{-1}$ threshold for DO concentrations below which $\mathrm{O}_{2}$ was sufficiently limiting to bacteria for denitrification to become thermodynamically favored. Applying this threshold value to the Otter Tail data for samples below $2 \mathrm{mg} \mathrm{L}^{-1} \mathrm{DO}$, the medians were $0.1 \mathrm{mg} \mathrm{L}^{-1}$ and $0.5 \mathrm{mg} \mathrm{L}^{-1}$ for $\mathrm{DO}$ and $\mathrm{NO}_{3}-\mathrm{N}$, respectively. For samples having DO concentrations $>2 \mathrm{mg} \mathrm{L}^{-1}$, DO and $\mathrm{NO}_{3}-\mathrm{N}$ were 7.5 and $11.5 \mathrm{mg} \mathrm{L}^{-1}$, respectively. This suggests that for a large portion of the samples $(43 \%)$, because of denitrification, $\mathrm{NO}_{3}-\mathrm{N}$ concentrations are much lower than would be expected.

Iron and Mn concentrations also displayed a large range from below detection to as high as 9.7 and $1.5 \mathrm{mg} \mathrm{L}^{-1}$, respectively. Such large concentrations of dissolved Fe and $\mathrm{Mn}$ are indications that the redox state of ground water has entered the stage where reduction of Fe and $\mathrm{Mn}$ oxides has replaced reduction of $\mathrm{O}_{2}$ and $\mathrm{NO}_{3}-\mathrm{N}$ in the terminal electron acceptor process.

Major ion chemistry was predominately $\mathrm{Ca}^{2+}, \mathrm{Mg}^{2+}$, and $\mathrm{HCO}_{3}{ }^{-}$, which is consistent with both what is known of the outwash mineralogy and agricultural applications. X-ray diffraction analyses of sediment samples revealed they were up to $15 \%$ calcite $\left(\mathrm{CaCO}_{3}\right)$ and $19 \%$ dolomite $\left[\mathrm{CaMg}\left(\mathrm{CO}_{3}\right)_{2}\right]$ although, values in the 1 to $3 \%$ range for each were more common. These values are also consistent with the 5 to $8 \%$ total carbonate values reported by Berndt (1987) for outwash deposits nearby in the vicinity of Bemidji, MN. In addition, farmers in the area typically apply 6.7 to $8.9 \mathrm{Mg} \mathrm{ha}^{-1} \mathrm{yr}^{-1}$ of dolomitic limestone (Denzel Cooper, 1996, Univ. of Minnesota Extension Service, oral communication). Infiltrating ground waters would therefore be expected to develop a carbonate signature as a result of calcite and dolomite dissolution.

Chloride and $\mathrm{SO}_{4}{ }^{2-}$ concentrations ranged as high as 56 and $93 \mathrm{mg} \mathrm{L}^{-1}$, respectively. Chloride commonly occurs in fertilizer as $\mathrm{KCl}$ and is a common contaminant associated with agricultural areas. With respect to $\mathrm{S}$, there is little available $\mathrm{S}$ in the outwash sediments; therefore, it is commonly supplied as an agricultural supplement either as gypsum $\left(\mathrm{CaSO}_{4} \cdot 2 \mathrm{H}_{2} \mathrm{O}\right)$ or in more recent years as ammonium sulfate $\left[\left(\mathrm{NH}_{4}\right)_{2} \mathrm{SO}_{4}\right]$.

\section{Land Use}

As stated above, area land use (Table 2) was predominately cropland, ranging from 56\% in the Perham area to $73 \%$ in the larger Otter Tail outwash aquifer study area. The Perham area had the largest area of pasture-grass and wetlands, whereas the larger study area had the most cropland and the least pasture-grass area. As a group, the wells were intermediate in cropland and pasture-grass area but had the largest areas of transportation and residential, commercial, and farmstead. In addition, the wells had no wetlands within their contributing areas. Crops grown in the area included corn (Zea mays L.), alfalfa, soybean, potato (Solanum tuberosum L.), wheat (Triticum aestivum L.), barley (Hordeum vulgare L.), oat (Avena sativa L.), and edible bean (Phaseolus sp.). The more intensive crops like corn, wheat, and potato were being rotated with alfalfa and soybean with $3 \mathrm{yr}$ of intensive crops followed by $3 \mathrm{yr}$ of less intensive crops. 


\section{Nitrogen Source and Sink Coefficients}

From 1992 to 1993 , approximately $11.9 \times 10^{3} \mathrm{Mg}$ of $\mathrm{N}$ was applied as commercial fertilizer in Otter Tail County. Assuming that commercial fertilizer is applied only on the 2189 $\mathrm{km}^{2}$ of county cropland, this gives a spatially averaged $\mathrm{N}$ application rate of $5426 \mathrm{~kg} \mathrm{~km}^{-2} \mathrm{yr}^{-1}$, making it one of the major potential $\mathrm{N}$ sources (Table 3). Volatilization loses of $\mathrm{NH}_{3}-\mathrm{N}$ from fertilizer accounted for $543 \mathrm{~kg} \mathrm{~km}^{-2} \mathrm{yr}^{-1}$.

Commercial feed for cattle was a source of about $57 \%$ more $\mathrm{N}$ than was removed in animal products (Table 3 ). In addition, the majority of what cattle consumed was supplied through grazing and by hay grown in the area-3253 of the total $4951 \mathrm{~kg} \mathrm{~N} \mathrm{~km}^{-2} \mathrm{yr}^{-1}$. The relatively small $\mathrm{N}$ amount removed in animal products is largely because the low conversion rate to biomass and the large amount returned in manure production $\left(3003 \mathrm{~kg} \mathrm{~N} \mathrm{~km}^{-2} \mathrm{yr}^{-1}\right)$. Volatilization loses of $\mathrm{NH}_{3}-\mathrm{N}$ from this manure accounted for $1051 \mathrm{~kg} \mathrm{~km}^{-2} \mathrm{yr}^{-1}$.

Nitrate $\mathrm{N}$ in precipitation from 1992 to 1993 (Table 4) ranged from 0.71 to $1.91 \mathrm{~kg} \mathrm{ha}^{-1}$ $\mathrm{yr}^{-1}$ with a mean of $1.42 \mathrm{~kg} \mathrm{ha}^{-1} \mathrm{yr}^{-1}$. Dry deposition of $\mathrm{NO}_{3}-\mathrm{N}$ ranged from 0.32 to $1.51 \mathrm{~kg} \mathrm{ha}^{-1}$ $\mathrm{yr}^{-1}$ with a mean of $0.96 \mathrm{~kg} \mathrm{ha}^{-1} \mathrm{yr}^{-1}$. Deposition of $\mathrm{NH}_{4}-\mathrm{N}$ ranged from 1.3 to $3.0 \mathrm{~kg} \mathrm{ha}^{-1} \mathrm{yr}^{-1}$ with a mean of $2.12 \mathrm{~kg} \mathrm{ha}^{-1} \mathrm{yr}^{-1}$. Total $\mathrm{N}$ deposition in precipitation therefore was estimated as $4.5 \mathrm{~kg} \mathrm{ha}^{-1} \mathrm{yr}^{-1}\left(450 \mathrm{~kg} \mathrm{~km}^{-2} \mathrm{yr}^{-1}\right)$ with $47 \%$ coming from $\mathrm{NH}_{4}-\mathrm{N}$ that had volatilized from fertilizer and manure. As Table 3 shows, atmospheric deposition is the smallest potential $\mathrm{N}$ source on a per- $\mathrm{km}^{2}$ basis.

Fixation was another major $\mathrm{N}$ source that was potentially larger than fertilizer, particularly for legumes (Table 3). For example, alfalfa can potentially fix $21800 \mathrm{~kg} \mathrm{~N} \mathrm{~km}^{-2} \mathrm{yr}^{-1}$. In areas where the alfalfa is harvested, much of the fixed $\mathrm{N}$ is removed. Under some management practices, however, it is merely plowed under at the end of the rotation, which creates a potentially large available source of organic $\mathrm{N}$ in the field that can later be mineralized and oxidized to $\mathrm{NO}_{3}-\mathrm{N}$. In the Otter Tail study area, only a small amount of this fixed $\mathrm{N}$ is fed to farm animals and the rest is harvested and sold outside the area.

Emissions of $\mathrm{NO}$ and $\mathrm{N}_{2} \mathrm{O}$ represented the smallest potential sinks for $\mathrm{N}$ ranging from 4 to 360 and 77 to $200 \mathrm{~kg} \mathrm{~km}^{-2} \mathrm{yr}^{-1}$, respectively. Both of these are intermediary by-products of nitrification and denitrification; processes in which $\mathrm{NO}_{3}{ }^{-}$and $\mathrm{N}_{2}$ gas are the primary end products. Consequently, as by-products it is not surprising that their potential contributions are relatively small.

\section{Mass-Balance Budget}

The $\mathrm{N}$ source and sink coefficients represent only the potential for gain or loss per $\mathrm{km}^{2}$. Because they integrate the sources and sinks into the overall mix of land use, however, the results of the mass-balance budget (Table 5) are indicative of $\mathrm{N}$ flow into, through, and out of the 212 $\mathrm{km}^{2}$ Otter Tail outwash aquifer agro-ecosystem (Fig. 2). Nitrogen inputs were dominated by fertilizer and fixation, with the latter being the greater of the two, accounting for $>53 \%$ of total 
$\mathrm{N}$ entering the system. Fertilizer is shown with other atmospheric sources in Fig. 2 because most is fixed industrially from atmospheric $\mathrm{N}$; however, throughout the report it is discussed individually.

Despite the fact that commercial feed represented a moderately large potential $\mathrm{N}$ source, because of the relatively small animal population in the study area, it was the smallest $\mathrm{N}$ source and accounted for only about $28.8 \mathrm{Mg} \mathrm{yr}^{-1}$. Even atmospheric deposition, at $96 \mathrm{Mg}$, accounted for three times as much $\mathrm{N}$.

Among the $\mathrm{N}$ sinks (Table 5), miscellaneous losses associated with cattle production, retention in wetlands and forests, manure volatilization, $\mathrm{N}_{2} \mathrm{O}$ emissions, and animal products accounted for only about $1 \%$ each, while NO emissions were about $3 \%$. Volatilization of $\mathrm{N}$ from fertilizer was about $5 \%$ of total lost, denitrification was about $10 \%$, and removal in harvested crops accounted for $76 \%$ of that lost, or about $68 \%$ of the $\mathrm{N}$ entering the system. The final net flux to ground water was about $229 \mathrm{Mg}$, which is three times the $76 \mathrm{Mg}$ that would be expected, assuming a national average background concentration of $2 \mathrm{mg} \mathrm{L}^{-1}$ in ground water (Mueller et al., 1995).

Two other sinks were added to the budget after the initial runs: forest retention and wetland-water retention. Estimated $\mathrm{N}$ inputs of 34 and $21 \mathrm{Mg}$ to forest and wetland-water areas, respectively, and estimated recharge rate of $17.7 \mathrm{~cm} \mathrm{yr}^{-1}$, resulted in predicted ground water $\mathrm{NO}_{3}-\mathrm{N}$ concentrations of 8.2 and $13.8 \mathrm{mg} \mathrm{L}^{-1}$, respectively. Because $\mathrm{NO}_{3}-\mathrm{N}$ concentrations $>2$ $\mathrm{mg} \mathrm{L}^{-1}$ in shallow ground water are considered atypical for undeveloped lands (Madison and

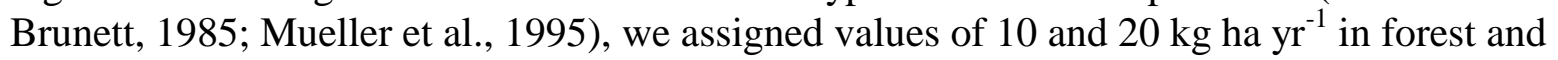
wetland-water areas, respectively, for $\mathrm{N}$ retained in living or dead biomass. These net retention values fall near the 5.5 and $17.5 \mathrm{~kg}$ ha $\mathrm{yr}^{-1}$ values reported for the Experimental Lakes Area in Ontario, Canada, and a site in Coshockton, OH (Likens and Bormann, 1995). The remaining inputs resulted in a more realistic estimated ground water $\mathrm{NO}_{3}-\mathrm{N}$ concentration of 2.4 to $2.5 \mathrm{mg}$ $\mathrm{L}^{-1}$.

Net flux to ground water estimate was based on median concentration of $\mathrm{NO}_{3}-\mathrm{N}$ in ground water $\left(6.1 \mathrm{mg} \mathrm{L}^{-1}\right)$ and estimated recharge rate of $17.7 \mathrm{~cm} \mathrm{yr}^{-1}$. We then assumed the difference between this net flux and total excess $\mathrm{N}(410.2 \mathrm{Mg}$ ) available for leaching was lost through denitrification. This seemed a reasonable assumption given that (i) as discussed above about $43 \%$ of sampled wells were in settings considered likely to support denitrification, and (ii) the $410.2 \mathrm{Mg}$ of excess $\mathrm{N}$ would have resulted in a predicted ground water $\mathrm{NO}_{3}-\mathrm{N}$ concentration of $10.9 \mathrm{mg} \mathrm{L}^{-1}$. In addition, wells that agreed closely with predicted $\mathrm{NO}_{3}-\mathrm{N}$ concentration were generally well oxygenated, whereas those that were much less than predicted by the budget had low DO's (suggesting denitrification). Resulting denitrification estimate of $181 \mathrm{Mg}$ represents almost half (44.1\%) of excess $\mathrm{N}$. Because of denitrification heterogeneity and the spatially average fertilizer application rate used, estimating $\mathrm{NO}_{3}-\mathrm{N}$ concentrations for individual wells is not practical. 


\section{Estimated Nitrate-Nitrogen Concentrations}

Table 6 lists the results of estimates calculated under various scenarios of crop harvests, $\mathrm{N}$ fixation, volatilization, fertilizer application rates, and changes in precipitation. With denitrification and net retention adjustments made to the budget, small variations in results of these simulations were caused by differences in land use makeup among the three study areas (Perham, Otter Tail, and well contributing areas). For this exercise we made the assumption that rate changes would not be offset by changes in denitrification.

Interestingly, the largest changes in $\mathrm{NO}_{3}-\mathrm{N}$ concentrations occurred as the result of changes in the amount of crop harvests. A 10\% increase in crop harvests resulted in a decrease in $\mathrm{NO}_{3}-\mathrm{N}$ concentrations of almost $2 \mathrm{mg} \mathrm{L}^{-1}$, while a $10 \%$ decrease resulted in an increase in $\mathrm{NO}_{3}-$ $\mathrm{N}$ concentrations of the same amount. The main reason for these dramatic changes in $\mathrm{NO}_{3}-\mathrm{N}$ concentrations is that under base conditions crop harvests remove about $76 \%$ of $\mathrm{N}$ lost from the system. Consequently, even small fluctuations can result in large amounts of excess $\mathrm{N}$ being removed from the system or leached to ground water. The greatest changes in $\mathrm{NO}_{3}-\mathrm{N}$ concentrations occurred in the Otter Tail and well contributing areas because of the larger cropland areas.

Changes in $\mathrm{N}$ fixation rates also resulted in some very large potential changes in $\mathrm{NO}_{3}-\mathrm{N}$ concentrations. For example, reducing miscellaneous fixation rate from 5 to $0 \mathrm{~kg} \mathrm{ha}^{-1} \mathrm{yr}^{-1}$ was approximately equivalent to a $10 \%$ reduction in fertilizer use; this response was not unexpected because the miscellaneous fixation rate was applied to the entire cropland area not planted in legumes. A 10\% reduction in alfalfa fixation produced a similar result. Setting the pasture-grass fixation rate from 15 to $0 \mathrm{~kg} \mathrm{ha}^{-1} \mathrm{yr}^{-1}$ had no effect in the well contributing areas, but reduced $\mathrm{NO}_{3}-\mathrm{N}$ concentrations markedly elsewhere, especially in the Perham study area, which contained the largest areas of that land use setting. Similarly, effects of changing $\mathrm{N}$ fixation in forest or wetlands-water settings were minor, except for the Perham area, which has the largest percentage of forests and wetlands.

A $10 \%$ increase or decrease in fertilizer use had large effects on ground water $\mathrm{NO}_{3}-\mathrm{N}$ concentrations, reflecting the large areas of cropland in all three study areas. Changes in fertilizer volatilization rate to 5 and $15 \%$ resulted in increases and decreases in concentrations of about 0.4 to $0.6 \mathrm{mg} \mathrm{L}^{-1}$, respectively; however, changes in manure volatilization rate to 25 and $50 \%$ had virtually no effect. A $10 \%$ decrease in atmospheric deposition reduced $\mathrm{NO}_{3}-\mathrm{N}$ concentrations by only $0.1 \mathrm{mg} \mathrm{L}^{-1}$.

Recharge rate variations also resulted in changes in $\mathrm{NO}_{3}-\mathrm{N}$ concentrations of similar magnitude to changes in fertilizer application rates. These changes were because an increase or decrease in volume of water reaching the water table would either dilute or concentrate dissolved constituents. Such variations in actual recharge rates in the field could therefore account for some of the variation seen in the well sample results. Naturally, at some point decreases in recharge rate should result in less $\mathrm{N}$ being transported from the surface to the water table; however, these simulations assume near-normal conditions. 
Overall, the budget seems most sensitive to changes in crop harvest, fertilizer use, $\mathrm{N}$ fixation by crops, and recharge to the water table. It should not come as a surprise that these factors would dominate the $\mathrm{N}$ cycle given that: (i) fertilizer and $\mathrm{N}$ fixation combined accounted for about $96 \%$ and crop harvest removed about $68 \%$ of $\mathrm{N}$ entering the system; (ii) cropland and pasture were the dominant land use (81\%); and (iii) approximately $40 \%$ of the cropland is in $\mathrm{N}$ fixing crops such as alfalfa, edible bean, and soybean.

\section{The Nitrogen Cycle}

The conceptual model for the Otter Tail outwash aquifer study area shown in Fig. 2 provides an overall perspective of sources, sinks, and mass transfers of $\mathrm{N}$ and relative magnitudes of each. It is immediately apparent that nonagricultural compartments of the cycle are negligible, largely because of the small portion of the study area in those settings (19\%). As indicated above, the budget is sensitive to changes in fixation rates and fixation is potentially a relatively large $\mathrm{N}$ source. Sensitivity to $\mathrm{N}$ fixation rates was because fixation rates for crops like alfalfa are so large that even small changes in fixation rate can produce dramatic changes in potentially available $\mathrm{N}$. However, most fixed $\mathrm{N}$ is assumed to be retained in living and dead biomass and is removed when crops are harvested, which leaves little to mineralize and leach to the water table. Approximately $97 \%$ of the $\mathrm{N}$ fixed by alfalfa, bean, and soybean is removed at harvest, suggesting that fertilizer is the primary source of excess $\mathrm{N}$ in cropland areas.

From Fig. 2, it is obvious that among the various compartments, cropland contributed the most (approximately 89\%) to total excess N. Because fertilizer and fixation inputs (1869 Mg) and crop removal exports $(1392 \mathrm{Mg}$ ) are so large compared with other sources and sinks in the cropland area, their difference (477 Mg) came close to the estimated excess $\mathrm{N}(410 \mathrm{Mg})$. The importance of crop harvests in removing $\mathrm{N}$ was dramatically shown in potential changes in ground water $\mathrm{NO}_{3}-\mathrm{N}$ concentrations resulting from hypothetical changes in crop harvests. Crop failures that occur after fertilizer applications are completed could result in leaching of large amounts of $\mathrm{NO}_{3}-\mathrm{N}$ to ground water; whereas, exceptionally good harvests could result in reduced leaching. These results point out the potential importance of ensuring that fertilizer applications not exceed optimum amounts, therefore, reducing ground water contamination and lessening the impact of crop failures.

Our results appear to demonstrate that fertilizer is the primary source of excess $\mathrm{NO}_{3}{ }^{-}$that leaches to ground water in these well drained outwash soils. However, there has been discussion in recent years on the relative value of reducing fertilizer application rates as a means of reducing $\mathrm{NO}_{3}{ }^{-}$leaching to ground water. Addiscott (1988) argued that long-term mineralization of soil organic matter is the source of excess $\mathrm{N}$ leaching to ground water, and because fertilizer $\mathrm{N}$ must pass through the soil organic matter pool "manipulating fertilizer use other than on a very longterm basis" cannot control $\mathrm{NO}_{3}{ }^{-}$leakage to ground water. Hanson and Djurhuus (1996) further demonstrated that use of a cover crop could be more efficient in reducing $\mathrm{NO}_{3}{ }^{-}$leaching than long-term low fertilizer application. Similar results using cover crops were reported by Thomsen et al. (1993) and by Beckwith et al. (1998). However, Hanson and Djurhuus (1996) also 
recognized the risk of leaching can be reduced by limiting fertilizer applications to the optimum level.

Lord and Mitchell (1998) showed that at higher than optimum application rates, more than half of the excess $\mathrm{N}$ could be accounted for in the $\mathrm{NO}_{3}{ }^{-}$leached to ground water. They

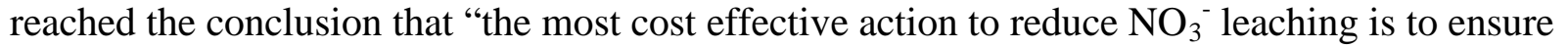
that inputs do not exceed the economic optimum." It has been estimated that in the USA, farmers typically apply 24 to $38 \%$ more $\mathrm{N}$ than is required (Babcock and Blackmer, 1992; Trachtenberg and Ogg, 1994). This 24 to $38 \%$ excess would amount to 9.5 to $15.1 \mathrm{~kg} \mathrm{~N}^{-1} \mathrm{yr}^{-1}$ compared with the $10.8 \mathrm{~kg} \mathrm{~N} \mathrm{ha}^{-1} \mathrm{yr}^{-1}$ we estimated. Also, were it not for denitrification losses, the average $\mathrm{NO}_{3}-\mathrm{N}$ leaching for the entire Otter Tail outwash aquifer study area would have been $19.3 \mathrm{~kg} \mathrm{~N}$ $\mathrm{ha}^{-1} \mathrm{yr}^{-1}$. Unfortunately, the use of cover crops, other than multiseason alfalfa plantings, in this area is negligible, so $\mathrm{N}$ from mineralized crop residues and excess fertilizer may readily leach to ground water. Therefore, our interpretation is that in these sandy outwash soils, controlling shortterm mineralization of crop residues and fertilizer $\mathrm{N}$ may be more important for reducing $\mathrm{NO}_{3}-\mathrm{N}$ leaching than long-term leaching from natural soil organic matter.

Although cattle and dairy production was small in the study area, it represented a net transfer between cropland and pasture-grass lands. We estimate that $10.8 \mathrm{Mg}$ more $\mathrm{N}$ is consumed by cattle as hay than was returned to cropland in manure and as a result, $6.6 \mathrm{Mg}$ more $\mathrm{N}$ was contributed to pastures in manure than was removed through grazing (Fig. 2). Cattle and dairy production resulted in a net export of $18.3 \mathrm{Mg}$ of $\mathrm{N}$ from the study area as beef and dairy products and $14.7 \mathrm{Mg}$ in animal biomass either in the form of nonconsumable products or waste. Net excess $\mathrm{N}$ estimated as $25.7 \mathrm{Mg}$ resulted in a $\mathrm{NO}_{3}-\mathrm{N}$ concentration of $8.5 \mathrm{mg} \mathrm{L}^{-1}$ in ground water originating solely from pasture and grass areas. This $25.7 \mathrm{Mg}$ of excess $\mathrm{N}$ can be entirely accounted for from inputs in atmospheric deposition $(7.6 \mathrm{Mg})$ and fixation $(25.5 \mathrm{Mg})$ suggesting that animal production was not contributing significantly to ground water contamination.

Even though atmospheric deposition was a source for $95.6 \mathrm{Mg}$ of $\mathrm{N}$ to the Otter Tail outwash aquifer study area, only $50.6 \mathrm{Mg}$ in the form of $\mathrm{NO}_{3}-\mathrm{N}$ was a true input. The remaining $45 \mathrm{Mg}$ occurred as $\mathrm{NH}_{4}-\mathrm{N}$, which is assumed to have originated within the study area after having volatilized as $\mathrm{NH}_{3}-\mathrm{N}$ from manure and fertilizer. Still, this $\mathrm{NH}_{4}-\mathrm{N}$ accounted for only about $46 \%$ of the $102 \mathrm{Mg}$ of volatilized $\mathrm{N}$; the remainder is assumed to have left the study area and been deposited elsewhere and therefore may be a true export from the ecosystem. There is uncertainty in the total amount that was exported because we were not able to estimate dry deposition of $\mathrm{NH}_{4}-\mathrm{N}$. If all the exported $\mathrm{NH}_{4}-\mathrm{N}$ were deposited within the study area, it would represent a net increase in atmospheric deposition of about $60 \%(152.6 \mathrm{Mg})$. This net increase in atmospheric deposition would have almost the same effect on ground water $\mathrm{NO}_{3}-\mathrm{N}$ as the $10 \%$ increase in fertilizer application shown in Table 6.

\section{CONCLUSIONS}

Both industrially fixed $\mathrm{N}$ in the form of inorganic fertilizer and organic $\mathrm{N}$ from $\mathrm{N}$ fixing crops dominate $\mathrm{N}$ cycling in the study area. Fixation of $\mathrm{N}$ by legumes, particularly alfalfa, 
represents a potentially large $\mathrm{N}$ source that exceeds that from inorganic fertilizer. Most fixed organic $\mathrm{N}$ is removed in harvested crops or as hay, however, and does not appear to present a threat to ground water. Also, because of the small size and dispersed nature of animal production in the area, it does not appear to contribute to ground water contamination. Instead, our analysis suggests that inorganic fertilizer is the primary source of $\mathrm{N}$ reaching shallow ground water. More importantly results suggest these sandy outwash soils may be unlike some agricultural lands where soil organic matter pool may play an important role in regulating $\mathrm{NO}_{3}-\mathrm{N}$ leaching. Instead, controlling short-term mineralization of crop residues and fertilizer $\mathrm{N}$, through the use of cover crops and optimizing fertilizer applications, may be more important for reducing $\mathrm{NO}_{3}-\mathrm{N}$ leaching.

After accounting for denitrification losses, ground water in the study area appears to be receiving approximately three times as much $\mathrm{N}$ than would be expected under natural conditions. Furthermore, denitrification removes almost half of the excess $\mathrm{N}$ leaching below the root zone and therefore appears to be a major factor in mitigating impacts of excess $\mathrm{N}$ to ground water. Further research is needed on the processes controlling $\mathrm{N}$ removal in outwash aquifers to limit and/or prevent contamination of ground water, particularly on the importance of soil organic matter pool and use of cover crops.

The mass-balance approach, combined with adequate ground water data, is a simple and convenient method for understanding flow of $\mathrm{N}$ within and through an agro-ecosystem. This approach provides a convenient conceptual framework for systematically studying $\mathrm{N}$ cycling in a variety of agricultural and hydrogeologic settings. Although the necessary crop and fertilizer data are readily available for most agricultural areas, ground water quality data seldom are, which is a factor that could greatly limit the utility of this approach. Fortunately, assessment programs in both the USA and Europe are gathering ground water quality data similar to that used in this study, making more large scale systematic studies of this nature possible in the future.

\section{ACKNOWLEDGMENTS}

This study was conducted as part of the U.S. Geological Survey National Water-Quality Assessment Program (NAWQA). We thank Thomas Nolan, Brian Hughes, and three anonymous reviewers for their comments, which were very helpful in revising the manuscript.

\section{REFERENCES}

Addiscott, T.M. 1988. Long-term leakage of nitrate from bare unmanured soil. Soil Use Manage. $4: 91-95$.

Anderson, J.L., G.R. Malzer, G.W. Randall, and G.W. Rehm. 1989. Nitrogen management related to groundwater quality in Minnesota. J. Minn. Acad. Sci. 55:53-57.

Anderson, J.R., E.E. Hardy, J.T. Roach, and R.E. Witmer. 1976. A land use and land cover classification system for use with remote sensor data. U.S. Geol. Surv. Prof. Pap. 964. 
Apsimon, H.M., M. Kruse, and J.N.B. Bell. 1987. Ammonia emissions and their role in acidic depositions of ammonia and ammonium in Europe. Atmos. Environ. 22:725-735.

Babcock, B.A., and A.M. Blackmer. 1992. The value of reducing temporal input nonuniformities. J. Agric. Res. Econ. 17:335-347.

Barry, D.A.J., D. Goorahoo, and M.J. Goss. 1993. Estimation of nitrate concentrations in groundwater using a whole farm nitrogen budget. J. Environ. Qual. 22:767-775.

Beckwith, C.P., J. Cooper, K.A. Smith, and M.A. Shepherd. 1998. Nitrate leaching loss following application of organic manures to sandy soils in arable cropping: I. Effects of application time, manure type, overwinter crop cover and nitrification inhibition. Soil Use Manage. 14:123-130.

Berndt, M.P. 1987. Metal partitioning in a sand and gravel aquifer contaminated by crude petroleum, Bemidji, Minnesota. M.S. thesis. Syracuse University.

Bohlke, J.K., and J.M. Denver. 1995. Combined use of groundwater dating, chemical, and isotopic analyses to resolve the history and fate of nitrate contamination in two agricultural watersheds, Atlantic coastal plain, Maryland. Water Resour. Res. 31:2319-2339.

Burns, R.C., and R.W.F. Hardy. 1975. Nitrogen fixation in bacteria and higher plants. SpringerVerlag, New York.

Chapelle, F.H., P.B. McMahon, N.M. Dubrovsky, R.F. Fujii, E.T. Oaksford, and D.A. Vroblevsky.1995. Deducing the distribution of terminal electron-accepting processes in hydrologically diverse groundwater systems. Water Resour. Res. 31:359-371.

Correll, D.L., T.E. Jordan, and D.E. Weller.1992. Nutrient flux in a landscape: Effects of coastal land use and terrestrial community mosaic on nutrient transport to coastal waters. Estuaries 15:431-442.

Cowdery, T.K. 1997. Shallow ground-water quality beneath cropland in the Red River of the North Basin, Minnesota and North Dakota, 1993-95. U.S. Geol. Surv. Water-Resour. Invest. Rep. 97-4001.

Davidson, E.A., and W. Kingerlee. 1997. A global inventory of nitric oxide emissions from soils. Nutr. Cycling in Agroecosystems. 48:37-50.

Delmas, R., D. Serca, and C. Jambert. 1997. Global inventory of $\mathrm{NO}_{\mathrm{x}}$ sources. Nutr. Cycling in Agroecosystems. 48:51-60.

Eichner, M.J. 1990. Nitrous oxide emissions from fertilized soils: Summary of available data. J. 
Environ. Qual. 19:272-280.

Fetter, C.W. 1994. Applied hydrology. 3rd ed. Prentice-Hall, Upper Saddle River, NJ.

Fishman, M.J. 1993. Methods of analysis by the U.S. Geological Survey National Water Quality Laboratory-determination of inorganic and organic constituents in water and fluvial sediments. U.S. Geol. Surv. Open-File Rep. 93-125.

Fishman, M.J., and L.C. Friedman. 1989. Methods for determination of inorganic substances in water and fluvial sediments. U.S. Geol. Surv. Tech. Water-Resour. Invest., Book 5. U.S. Gov. Print. Office, Washington, DC.

Gillham, R.W., and J.A. Cherry. 1978. Field evidence of denitrification in shallow groundwater flow systems. Water Pollut. Res. J. Can. 13:53-71.

Goldstein, B.S. 1985. Stratigraphy, sedimentology, and Late-Quaternary history of the Wadena Drumlin Region, central Minnesota. Ph.D. thesis. Univ. of Minnesota, Minneapolis.

Hall, D.H., and D.W. Risser. 1993. Effects of agricultural nutrient management on nitrogen fate and transport in Lancaster County, Pennsylvania. Water Resour. Bull. 29:55-76.

Hanson, E.M., and J. Djurhuus. 1996. Nitrate leaching as affected by long-term $\mathrm{N}$ fertilization on coarse sand. Soil Use Manage. 12:199-204.

Hutchinson, G.L., M.F. Vigil, J.W. Doran, and A. Kessavalou. 1997. Coarse-scale soilatmosphere $\mathrm{NO}_{\mathrm{x}}$ exchange modeling: Status and limitations. Nutr. Cycling in Agroecosystems 48:25-35.

Jaworski, N.A., P.M. Groffman, A.K. Keller, and J.C. Prager. 1992. A watershed nitrogen and phosphorus balance: The Upper Potomac River Basin. Estuaries 15:83-95.

Jordan, T.E., and D.E. Weller. 1996. Human contributions to terrestrial nitrogen flux. BioScience $46: 655-664$.

Keeney, D.R. 1979. A mass balance of nitrogen in Wisconsin. Wis. Acad. of Sci., Arts and Lett. 67:95-102.

Koterba, M.T., F.D. Wilde, and W.W. Lapham. 1995. Ground-water data-collection protocols and procedures for the National Water-Quality Assessment Program-collection and documentation of water-quality samples and related data. U.S. Geol. Surv. Open-File Rep. 95399.

Likens, G.E., and F.H. Bormann. 1995. Biogeochemistry of a forested ecosystem. SpringerVerlag, New York. 
Lord, E.I., and R.D.J. Mitchell. 1998. Effect of nitrogen inputs to cereals on nitrate leaching from sandy soils. Soil Use and Manage. 14:78-83.

MacGregor, A.N., and D.R. Keeney. 1975. Nutrient reactions, p. 237-257. In N.F. Stanley and M.P. Alpers (ed.) Man-made lakes and human health. Academic Press, London.

Madison, R.J., and J.O. Brunett. 1985. Overview of the occurrence of nitrate in ground water of the United States. p. 93-105. In National Water Summary 1984. U.S. Geol. Surv. Water-Supply Pap. 2275.

McDonald, M.C., and A.W. Harbaugh. 1988. A modular three-dimensional finite-difference ground-water flow model. U.S. Geol. Surv. Tech. Water-Resour. Invest. Book 6.

McMahon, G., and M.D. Woodside. 1997. Nutrient mass balance of the Albemarle-Pamlico Drainage Basin, North Carolina and Virginia, 1990. J. Am. Water Res. Assoc. 33:573-589.

Menheer, M.A., and M.E. Brigham. 1997. National Water-Quality Assessment Programground-water sampling methods and quality control for the Red River of the North Basin, 19931995. U.S. Geol. Surv. Water-Resour. Invest. Rep. 96-4317.

Messer, J., and P.L. Brezonick. 1983. Agricultural nitrogen model: A tool for regional environmental management. Environ. Manage. 7:177-187.

Minnesota Agricultural Statistics Service. 1993. Minnesota agricultural statistics 1993. Minnesota Agric. Stat. Serv., St. Paul, MN.

Modica, E., H.T. Buxton, and L.N. Plummer. 1998. Evaluating the source and residence times of groundwater seepage to streams, New Jersey Coastal Plain. Water Resour. Res. 34:2792-2810.

Mueller, D.K., P.A. Hamilton, D.R. Helsel, K.J. Hitt, and B.C. Ruddy. 1995. Nutrients in ground water and surface water of the United States-An analysis of data through 1992. U.S. Geol. Surv. Water-Resour. Invest. Rep. 95-4031.

Peterson, T.A., and M.P. Russelle. 1991. Alfalfa and the nitrogen cycle in the corn belt. J. Soil Water Conserv. 46:229-235.

Pollock, D.W. 1989. Documentation of computer programs to compute and display pathlines using results from the U.S. Geological Survey modular three-dimensional finite-difference ground-water flow model. U.S. Geol. Surv. Open-File Rep. 89-381.

Puckett, L.J. 1995. Identifying the major sources of nutrient water pollution. Environ. Sci. Technol. 29:408A-414A. 
Reeder, H.O. 1972. Availability of ground water for irrigation from glacial outwash in the Perham area, Otter Tail County, Minnesota. U.S. Geol. Surv. Water-Supply Pap. 2003.

Schlesinger, W.H., and A.E. Hartley. 1992. A global budget for atmospheric $\mathrm{NH}_{3}$. Biogeochemistry 15:191-211.

Sisterson, D.L. 1990. Detailed $\mathrm{SO}_{\mathrm{x}}-\mathrm{S}$ and $\mathrm{No}_{\mathrm{x}}-\mathrm{N}$ mass budgets for the United States and Canada. p. In Acidic deposition-state of the science and technology. p. 8A-1-8A-10. National Acid Precipitation Assessment Program, Washington, DC.

Skiba, U., D. Fowler, and K.A. Smith. 1997, Nitric oxide emissions from agricultural soils in temperate and tropical climates: Sources, controls, and mitigation options. Nutr. Cycling in Agroecosystems 48:139-153.

Stevenson, F.J. 1982. Origin and distribution of nitrogen in soils. p. 1-42. In F.J. Stevenson (ed.) Nitrogen in agricultural soils. Agron. Monogr. 22. ASA, CSSA, and SSSA, Madison, WI.

Stoner, J.D., D.L. Lorenz, G.J. Wiche, and R.M. Goldstein. 1993. Red River of the North Basin, Minnesota, North Dakota, and South Dakota. Water Resour. Bull. 29:575-615.

The Fertilizer Institute. 1982. The fertilizer handbook. The Fertilizer Inst., Washington, DC.

Thomas, G.W., and J.W. Gilliam. 1977. Agro-ecosystems in the USA. Agro-Ecosystems 4:182243.

Thomsen, I.K., J.F. Hansen, V. Kjellerup, and B.T. Christensen. 1993. Effects of cropping and rates of nitrogen in animal slurry and mineral fertilizer on nitrate leaching from a sandy loam. Soil Use and Manage. 9:53-58.

Trachtenberg, E., and C. Ogg. 1994. Potential for reducing nitrogen pollution through improved agronomic practices. Water Resour. Bull. 30:1109-1118.

U.S. Environmental Protection Agency. 1996. Drinking water regulations and health advisories. USEPA, Washington, DC.

Vitousek, P.M. 1994. Beyond global warming: Ecology and global change. Ecology 75: 18611876.

Wershaw, R.L., M.J. Fishman, R.R. Grabbe, and L.E. Lowe. 1987. Methods for the determination of organic substances in water and fluvial sediments. U.S. Geol. Surv. Tech. of Water-Resour. Invest. Book 5. U.S. Gov. Print. Office, Washington, DC.

Winter, T.C., and M.K. Woo. 1990. Hydrology of lakes and wetlands. p. 159-187. In M.G. Wolman and H.C. Riggs (ed.) Surface water hydrology: The geology of North America. Vol. O- 
1. Geol. Soc. of Am., Boulder, CO.

Wright, Jr., H.E. 1972. Quaternary history of Minnesota, p. 540-543. In P.K. Sims, and G.B. Morey (ed.) Minnesota—a centennial volume. Minnesota Geol. Surv., St. Paul, MN. 
Table 1. Concentrations of selected constituents in ground water from 29 randomly sampled wells (28 in the case of nutrients) located throughout the $212.4 \mathrm{~km}^{2}$ Otter Tail outwash aquifer study area. All units are $\mathrm{mg} \mathrm{L}^{-1}$ with the exception of $\mathrm{Fe}^{2+}$ and $\mathrm{Mn}^{2+}$ which are $\mu \mathrm{g} \mathrm{L}^{-1}$

\begin{tabular}{lrr}
\hline Constituent & Median & \multicolumn{1}{c}{ Range } \\
\hline $\mathrm{Na}^{+}$ & 2.4 & $1.3-21.0$ \\
$\mathrm{~K}^{+}$ & 1.3 & $0.2-6.7$ \\
$\mathrm{Ca}^{2+}$ & 76.0 & $45-120$ \\
$\mathrm{Mg}^{2+}$ & 20.0 & $12-38$ \\
$\mathrm{HCO}_{3}{ }^{-}$ & 254.5 & $138-373$ \\
$\mathrm{Cl}^{-}$ & 7.6 & $0.7-56$ \\
$\mathrm{SO}_{4}{ }^{2-}$ & 12.0 & $2.3-93$ \\
$\mathrm{NO}_{3}-\mathrm{N}$ & 6.1 & $0-46$ \\
$\mathrm{NH}_{4}-\mathrm{N}$ & 0.0 & $0.0-0.3$ \\
$\mathrm{Org}_{-} \mathrm{N}$ & 0.1 & $0.1-0.6$ \\
$\mathrm{PO}_{4}-\mathrm{P}$ & 0.0 & $0.0-0.2$ \\
$\mathrm{Fe}^{2+}$ & 45 & $4-9700$ \\
$\mathrm{Mn}$ & 14 & $0-1500$ \\
$\mathrm{DOC}$ & 2.1 & $0.6-11$ \\
$\mathrm{DO}$ & 3.6 & $0.1-10.1$ \\
\hline
\end{tabular}

Table 2. Land use in the study areas expressed as a percent of total land use

\begin{tabular}{lccc}
\hline Land use & Otter Tail & Perham & Wells $^{\dagger}$ \\
\hline Cropland & 73 & 56 & 65 \\
Pasture/Grass & 8 & 20 & 11 \\
Residential/Commercial & 3 & 2 & 9 \\
Transport & 1 & 1 & 9 \\
Forest & 11 & 10 & 6 \\
Wetland/Water & 4 & 11 & 0 \\
\hline
\end{tabular}

${ }^{\dagger}$ The contributing areas of all the wells sampled as part of the study. 
Table 3. Source and sink coefficients used in the mass-balance budget. Items followed by a "+" are sources and those followed by a "-" are sinks.

\begin{tabular}{|c|c|c|c|}
\hline \multicolumn{2}{|l|}{ Sources/Sinks } & \multirow{2}{*}{$\begin{array}{l}\text { Coefficient } \\
\mathrm{kg} \mathrm{N} \mathrm{km}^{-2}\end{array}$} & \multirow{2}{*}{$\begin{array}{c}\text { Area } \\
\mathrm{km}^{2}\end{array}$} \\
\hline & & & \\
\hline Atmospheric deposition & + & 450.0 & 212.4 \\
\hline Fertilizer volatilization & - & 542.6 & 155.0 \\
\hline Forest retention & - & 1000.0 & 23.4 \\
\hline Manure volatilization & - & 1050.9 & 17.0 \\
\hline Animal products & - & 1074.9 & 17.0 \\
\hline Commercial feed & + & 1697.7 & 17.0 \\
\hline Wetland/water retention & - & 2000.0 & 8.5 \\
\hline Manure & $t$ & 3002.6 & 17.0 \\
\hline Fertilizer & + & 5426.4 & 155.0 \\
\hline Crop harvest & - & 9153.2 & 155.0 \\
\hline \multicolumn{4}{|l|}{ Nitrogen fixation } \\
\hline Cropland & + & 500 & 93.8 \\
\hline Forest & + & 1000 & 23.4 \\
\hline Pasture/Grass & + & 1500 & 17.0 \\
\hline Wetland/Water & + & 2000 & 8.5 \\
\hline Edible Beans & + & 4000 & 1.2 \\
\hline Soybeans & + & 7800 & 23.7 \\
\hline Alfalfa & + & 21800 & 36.3 \\
\hline \multicolumn{4}{|l|}{ Nitric oxide } \\
\hline Cropland & - & 360 & 155.0 \\
\hline Forest & - & 10 & 23.4 \\
\hline Pasture/Grass & - & 120 & 17.0 \\
\hline Wetland/Water & - & 4 & 8.5 \\
\hline \multicolumn{4}{|l|}{ Nitrous oxide } \\
\hline Cropland & - & 77 & 155.0 \\
\hline Legumes & - & 200 & 61.2 \\
\hline
\end{tabular}

${ }^{\dagger}$ Manure was used to account for internal transfers, not as an external input to the system. 
Table 4. Estimated annual atmospheric deposition of nitrogen $\left(\mathrm{kg} \mathrm{ha}^{-1}\right)$ in both wet and dry forms

\begin{tabular}{|c|c|c|c|c|c|}
\hline \multirow[t]{2}{*}{ Site } & \multirow[t]{2}{*}{ Year } & \multicolumn{2}{|c|}{$\mathrm{NO}_{3}-\mathrm{N}$} & $\mathrm{NH}_{4}-\mathrm{N}$ & Total \\
\hline & & Wet & Dry & & \\
\hline MN23 & 1992 & 1.82 & 1.44 & 3.00 & 6.26 \\
\hline MN23 & 1993 & 1.91 & 1.51 & 2.20 & 5.62 \\
\hline ND11 & 1992 & 0.71 & 0.32 & 1.30 & 2.33 \\
\hline ND11 & 1993 & 1.24 & 0.56 & 1.97 & 3.77 \\
\hline Mean & & 1.42 & 0.96 & 2.12 & 4.50 \\
\hline
\end{tabular}

Table 5. Estimates of sources and sinks of nitrogen $(\mathrm{Mg})$ for the $212.4 \mathrm{~km}^{2}$ Otter Tail outwash aquifer study area

\begin{tabular}{lrr}
\hline & & \\
Sources & Mg & $\%$ \\
\hline Commercial Feed & 28.8 & 1.4 \\
Atmospheric Deposition & 95.6 & 4.6 \\
Fertilizer & 841.3 & 40.9 \\
Fixation & 1093.8 & 53.1 \\
\hline Subtotal & 2059.4 & 100.0 \\
\hline Sinks & & \\
\hline Cattle (Other) & 14.7 & 0.8 \\
Wetland/Water Retention & 17.0 & 0.9 \\
Manure Volatilization & 17.9 & 1.0 \\
Animal Products & 18.3 & 1.0 \\
Forest Retention & 23.4 & 1.3 \\
Nitrous oxide losses & 24.2 & 1.3 \\
Nitric oxide losses & 58.0 & 3.2 \\
Fertilizer Volatilization & 84.1 & 4.6 \\
Denitrification & 180.9 & 9.9 \\
Crop Harvest & 1391.5 & 76.0 \\
\hline Subtotal & 1830.1 & 100.0 \\
\hline Net Flux & & \\
\hline
\end{tabular}


Table 6. Estimates of ground water $\mathrm{NO}_{3}-\mathrm{N}$ concentrations $\left(\mathrm{mg} \mathrm{L}^{-1}\right)$ under various scenarios of changes in sources and sinks

\begin{tabular}{|c|c|c|c|}
\hline Scenario & Otter Tail & Perham & Wells \\
\hline Base condition & 6.1 & 6.1 & 6.1 \\
\hline \multicolumn{4}{|l|}{ Recharge } \\
\hline $10 \%$ decrease $(15.9 \mathrm{~cm})$ & 6.8 & 6.8 & 6.8 \\
\hline $10 \%$ increase $(19.5 \mathrm{~cm})$ & 5.5 & 5.5 & 5.5 \\
\hline \multicolumn{4}{|l|}{ Crop harvest } \\
\hline $10 \%$ increase & 4.3 & 4.6 & 4.2 \\
\hline $10 \%$ decrease & 7.9 & 7.6 & 8.0 \\
\hline \multicolumn{4}{|l|}{ Fertilizer } \\
\hline $10 \%$ increase & 7.1 & 6.9 & 7.1 \\
\hline $10 \%$ decrease & 5.2 & 5.3 & 5.1 \\
\hline \multicolumn{4}{|l|}{ Atmospheric deposition } \\
\hline $10 \%$ increase & 6.2 & 6.2 & 6.2 \\
\hline $10 \%$ decrease & 6.0 & 6.0 & 6.0 \\
\hline \multicolumn{4}{|l|}{ Fertilizer volatilization } \\
\hline $50 \%$ increase $(15 \%)$ & 5.6 & 5.7 & 5.5 \\
\hline $50 \%$ decrease $(5 \%)$ & 6.6 & 6.5 & 6.7 \\
\hline \multicolumn{4}{|l|}{ Manure volatilization } \\
\hline $43 \%$ increase $(50 \%)$ & 6.0 & 6.1 & 6.1 \\
\hline $29 \%$ decrease $(25 \%)$ & 6.2 & 6.1 & 6.1 \\
\hline \multicolumn{4}{|l|}{ Fixation } \\
\hline $\begin{array}{l}\text { Miscellaneous } \\
\text { None }\end{array}$ & 5.1 & 5.3 & 5.0 \\
\hline $\begin{array}{l}\text { Forest } \\
\qquad 1000 \mathrm{~kg} \mathrm{~km}^{-2}\end{array}$ & 6.4 & 6.4 & 6.1 \\
\hline $\begin{array}{l}\text { Pasture/Grass } \\
\text { None }\end{array}$ & 5.8 & 5.2 & 6.1 \\
\hline $\begin{array}{l}\text { Wetlands/Water } \\
2000 \mathrm{~kg} \mathrm{~km}^{-2}\end{array}$ & 6.3 & 6.8 & 6.1 \\
\hline $\begin{array}{l}\text { Alfalfa } \\
\quad 10 \% \text { decrease }\end{array}$ & 5.1 & 5.3 & 5.0 \\
\hline
\end{tabular}




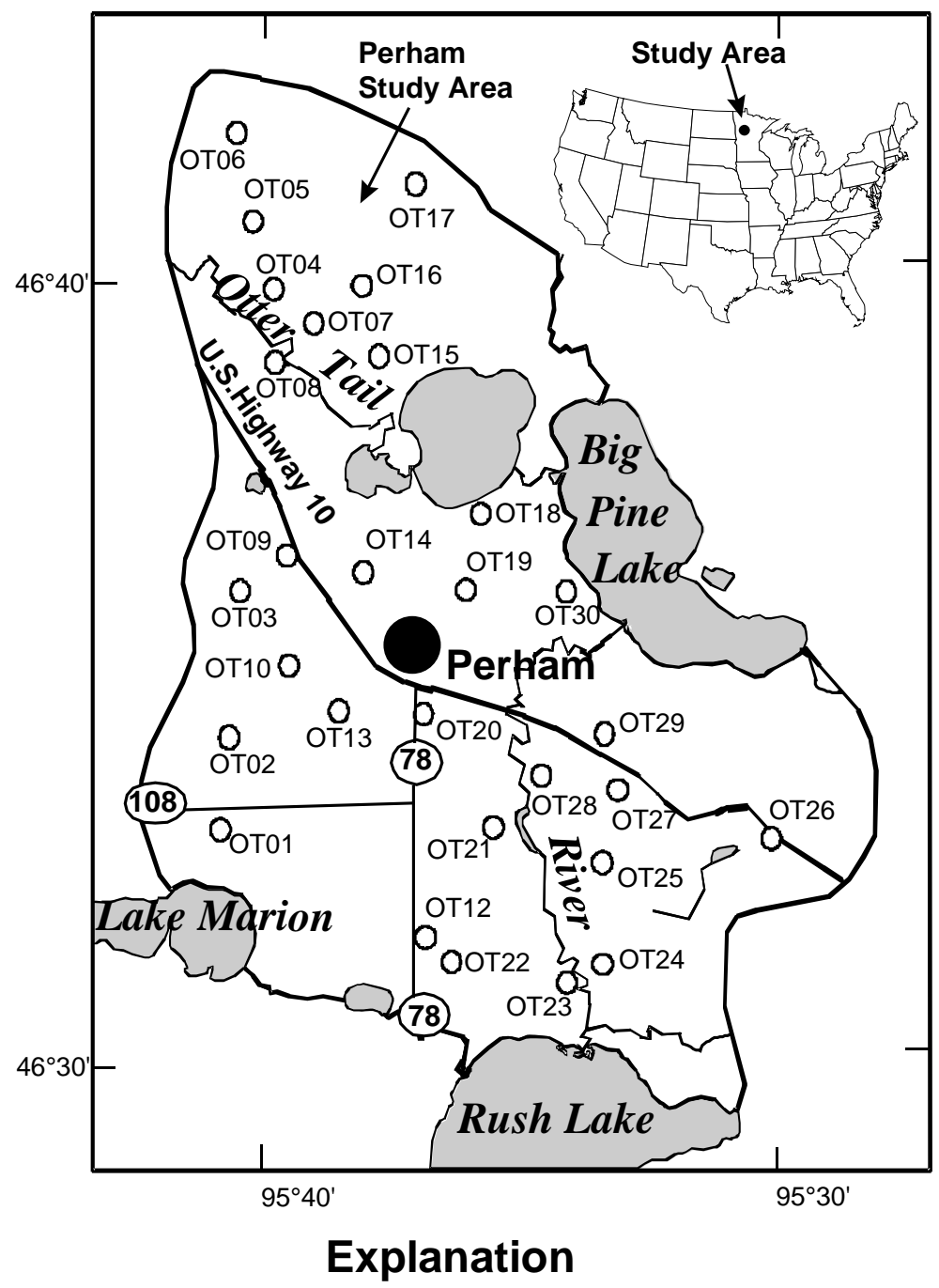

ООт20 Well location and well number

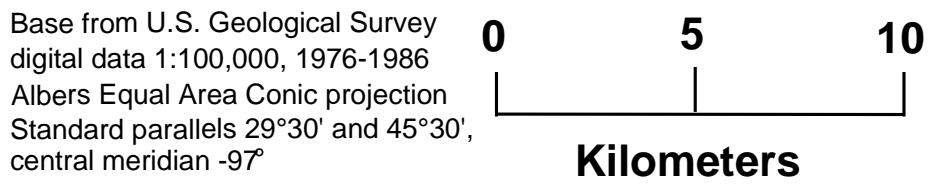

Puckett, Estimation of nitrate contamination of an outwash aquifer using a nitrogen mass-balance budget, fig. 1

Fig. 1. The Otter Tail outwash aquifer study area showing locations of individual wells sampled. 


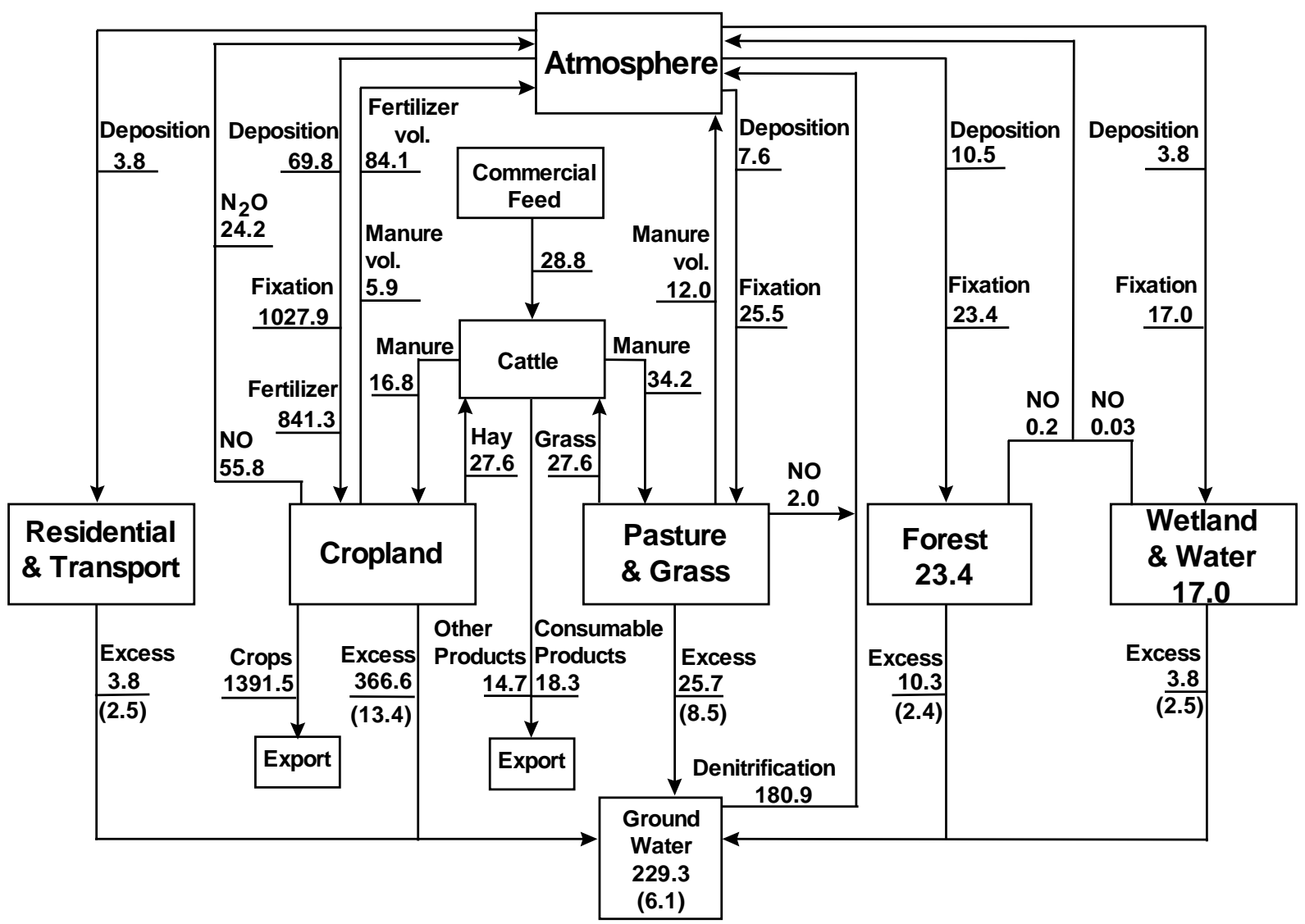

Puckett, Estimation of nitrate contamination of an outwash aquifer using a nitrogen mass-balance budget, fig. 2

Fig. 2. The flow of $\mathrm{N}\left(\mathrm{Mg} \mathrm{yr}^{-1}\right)$ in the $212.4 \mathrm{~km}^{2}$ Otter Tail outwash aquifer study area. Lines and associated values represent $\mathrm{N}$ fluxes; values in boxes are net retention or other losses except in the case of ground water, which is the total flux of $\mathrm{N}$ reaching the water table. Values in parentheses are predicted $\mathrm{NO}_{3}-\mathrm{N}$ concentrations $\left(\mathrm{mg} \mathrm{L}^{-1}\right)$ for the given $\mathrm{N}$ flux. 